\title{
THE INFLUENCE OF PHENOLS AND OTHER COMPOUNDS ON CHEMICAL OXYGEN DEMAND (COD) OF PHENOLIC WATERS FROM THE KIVITER PROCESS
}

\author{
L. KEKISHEVA ${ }^{(\mathrm{a})^{*}}$, I. SMIRNOV $^{(\mathrm{a})}$, N. OSTROUKHOV ${ }^{(\mathrm{b})}$,

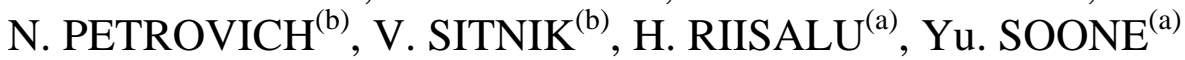 \\ (a) Department of Oil Shale Technology, \\ Tallinn University of Technology \\ 35 Järveküla tee, 30328 Kohtla-Järve, Estonia \\ (b) VKG OIL Ltd. \\ 14 Järveküla tee, 30328 Kohtla-Järve, Estonia
}

\begin{abstract}
The contribution of chemical oxygen demand of phenols and other oxidizable compounds to chemical oxygen demand of phenol waters at co-processing of shale oils of the Kiviter process and oil fractions of the Galoter process has been investigated.
\end{abstract}

\section{Introduction}

In connection with increasing demand for oil shale phenols, Viru Chemistry Group, Ltd. has started co-processing of oils obtained at oil shale retorting in vertical retorts (the Kiviter process [1]) with oil fractions produced at Oil Plant of Narva Power Plants Ltd., where oil shale is processed in the solid heat carrier units (the Galoter process). However, co-treatment of oils has created some problems caused by an increase in the value of chemical oxygen demand (COD) in both the phenolic water and the dephenolized water. That, in turn, complicates biological treatment of the waters. A detailed investigation is needed to assess the influence of phenols and other organic compounds on COD of waters before and after dephenolation.

Chemical oxygen demand, biological oxygen demand (BOD), total nitrogen content and total phosphorus content are the most significant parameters characterizing ecological danger of wastewaters. Among them COD is the most used. Under condition of joint discharge of municipal and industrial wastewaters into the soil or some water reservoir, COD value of biologically

*Corresponding author: e-mail expertfield1@hot.ee 
treated water should not exceeded $125 \mathrm{mg} / \mathrm{L}$, in the case of industrial wastewater only the limit is $250 \mathrm{mg} / \mathrm{L}$. The maximum permissible concentration (MPC) of monobasic phenols in the effluent discharge is $0.1 \mathrm{mg} / \mathrm{L}$, that of dibasic phenols $-15 \mathrm{mg} / \mathrm{L}$ [2].

Dephenolized water from the Kiviter process, other industrial waters and domestic wastewaters are purified together in the wastewater treatment plant by aerobic treatment. However, mixing of industrial and domestic waters leads to a COD/BOD ratio more favorable for biodegratation resulting in a decrease in the COD value. According to the COD value, wastewaters directed to biological treatment are classified as follows: low-concentrated (COD $1-5 \mathrm{~kg} / \mathrm{m}^{3}$ ), concentrated (COD $5-20 \mathrm{~kg} / \mathrm{m}^{3}$ ) and high-concentrated $\left(C O D>20 \mathrm{~kg} / \mathrm{m}^{3}\right)$ ones [3]. Dephenolized water from the dephenolation plant of Viru Chemistry Group Ltd. belongs to the first-mentioned group.

Kahru and Põllumaa [4] have studied the dependence of COD and BOD on concentration of total phenols in semicoke eluents. However, there are no data on how COD of phenols influences COD of phenolic waters.

Phenolic water, formed at oil shale thermal processing, contains a wide range of compounds (mono- and dibasic phenols, carboxylic acids, ketones, basic nitrogen compounds and others), influencing the process of dephenolation and the content of chemical compounds in dephenolized water [5].

Data on quantity and quality of phenols extracted with water from shale oil fractions are given in [6,7]. A particular feature of this water is prevalence of alkyl resorcinols [7].

The concentration of phenolic substances dissolved in water depends on the process of oil shale treatment and on the conditions of the contact between oil and water in condensers and decanters. Phenol content of the Galoter phenolic water is $1-2 \mathrm{~g} / \mathrm{L}$ [6], that of the Kiviter phenolic water $-8.5-12 \mathrm{~g} / \mathrm{L}$ [5]. The content of other compounds in water entering the dephenolation plant is as follows: carboxylic acids $0.3-0.4 \mathrm{~g} / \mathrm{L}$, ketones $-0.1-0.2 \mathrm{~g} / \mathrm{L}$, basic nitrogen compounds (mostly pyridine, picolines, toluidine) $-0.05-0.1 \mathrm{~g} / \mathrm{L}$ [5].

Among carboxylic acids, acetic (90\%) and propionic (about 7\%) acids prevail. Carbonyl compounds in retort water are represented by ketones with carbonyl group in position 2 (methyl ketones) $[6,8]$, acetone (about 85\%) and methyl ethyl ketone (about 12\%).

Among sulfur compounds hydrogen sulfide prevails [6], a component that oxidizes easily. Group composition of sulphur compounds in products of oil shale treatment has been studied by Metsik with coworkers [9].

Phenol content of dephenolized water may vary between 0.2 and $1.3 \mathrm{~g} / \mathrm{L}$ $[7,10]$. At reduction of the extent of extraction efficiency (phenol concentration remains higher), the ratio of 5-methyl resorcinol (5-MR) to resorcinol may even exceed three [6]. However, there are no data on the influence of COD values of phenols on the total COD value of phenolic waters.

The purpose of this research was to study the influence of phenol concentration on COD of waters before and after the dephenolation stage at coprocessing of Kiviter and Galoter shale oils. 


\section{Experimental}

\section{Model samples of shale oil and their extraction with water}

The initial sample of Kiviter retort oil consists of $48 \mathrm{wt} . \%$ light-middle oil, $26 \mathrm{wt} . \%$ heavy oil and $26 \mathrm{wt} . \%$ gasoline fraction. This sample was prepared by blending $52 \mathrm{wt} . \%$ clarified oil (treated heavy oil containing $50 \%$ gasoline fraction) with $48 \mathrm{wt} . \%$ light-middle oil.

The model mixture consisting of Kiviter oil and A- or B-grade Galoter oils was made by complete or partial alternate substitution of B-grade oil for light-middle oil and A-grade oil for heavy oil. As for physical and chemical properties, A-grade oil is more dense and more viscosous than B-grade oil and its flash point is higher as well.

At water extraction tests, A-grade oil was diluted by a half and B-grade oil by a third with gasoline fraction (boiling $<200{ }^{\circ} \mathrm{C}$ and obtained at distillation of Kiviter retort oil).

Characteristics of shale oils and oil mixture are given in Table 1.

Test samples of A- and B-grade shale oils meet the local standard [10].

Compositions of shale oil mixtures used in water-washing tests are presented in Table 2.

Because gasoline fraction (sample 10) from Viru Chemistry Group Ltd. Oil Plant is used for diluting oils, its water extract was also analyzed.

Shale oil samples were extracted with water in 1.0-L separating funnels. Heated to $65{ }^{\circ} \mathrm{C}$ distilled water was added to the test sample (oil to water $1: 1$ ), agitated for $30 \mathrm{~min}$, settled for one hour at $50-55^{\circ} \mathrm{C}$, after what water layer was separated.

The obtained water samples were analysed for phenol content using differential ultraviolet spectroscopy [12], and for carbonyl compounds by measuring the consumption of hydroxylamine chloride (oxymation reaction). For determination of volatile acids and bases, water samples were distilled and the distillates titrated to $\mathrm{pH} 9$ (volatile bases) and to $\mathrm{pH}$ 1-2 (volatile acids). Standard methods were used to determine ammonium nitrogen [13] and COD [14]. Laboratory samples of phenolic water are characterized in Table 2.

Table 1. Properties of shale oils

\begin{tabular}{|l|c|c|c|}
\hline \multirow{2}{*}{ Item } & \multicolumn{3}{|c|}{ Shale oil } \\
\cline { 2 - 4 } & Prepared sample & Grade A & Grade B \\
\hline Density at $20{ }^{\circ} \mathrm{C}, \mathrm{kg} / \mathrm{m}^{3}$ & 915 & 1020 & 970 \\
Kinematic viscosity at $50{ }^{\circ} \mathrm{C}, \mathrm{mm}^{2} / \mathrm{s}$ & 5.8 & 73 & 16.7 \\
Solids, wt.\% & 0.04 & 0.19 & 0.08 \\
Ash,wt.\% & 0.02 & 0.12 & 0.06 \\
Water, wt.\% & 1.7 & 0.2 & 0.2 \\
Elemental analysis, wt.\%: & & & \\
$\quad \mathrm{C}$ & 82.1 & 83.1 & 81.8 \\
$\mathrm{H}$ & 9.4 & 9.7 & 9.6 \\
$\mathrm{~S}$ & 0.7 & 0.5 & 0.6 \\
$\mathrm{O}+\mathrm{N}$ & 7.8 & 6.7 & 8.0 \\
\hline
\end{tabular}




\begin{tabular}{|c|c|c|c|c|c|}
\hline \multirow{10}{*}{ 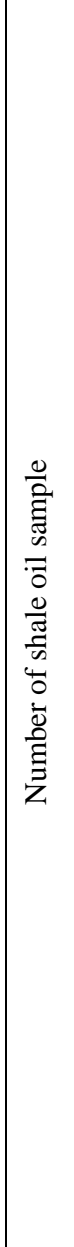 } & 잉 & $£$ & $\begin{array}{l}\stackrel{0}{\circ} \infty \\
+\infty\end{array}$ & 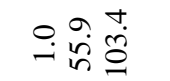 & $\stackrel{\circ}{\circ}$ \\
\hline & $a$ & I $\& \underset{T}{U}$ & $\begin{array}{l}\vec{\infty} \bar{i} \\
+ \\
\dot{N}\end{array}$ & 웃 $\stackrel{0}{\dot{i}} \stackrel{0}{\dot{\infty}}$ & $\begin{array}{l}\stackrel{0}{\mathrm{i}} \\
\stackrel{\mathrm{I}}{ }\end{array}$ \\
\hline & $\infty$ & ニ $\& \stackrel{+}{+}$ & $\underset{+}{\stackrel{+}{+}} \stackrel{\infty}{=}$ & ঢ: & $\stackrel{\sim}{\ddot{n}}$ \\
\hline & $r$ & กีd & $\stackrel{+}{\stackrel{+}{+}}$ & 윰ํำ & $\stackrel{0}{9}$ \\
\hline & 0 & $\tilde{n} \stackrel{\infty}{+}$ & 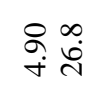 & 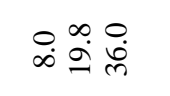 & $\stackrel{n}{\varrho}$ \\
\hline & in & 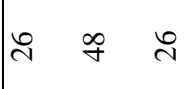 & $\stackrel{\sigma}{\sigma}$ & 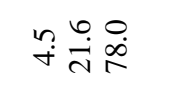 & $\stackrel{n}{?}$ \\
\hline & $\theta$ & $\stackrel{\infty}{\sim} \quad \stackrel{+}{+}$ & 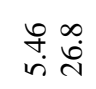 & 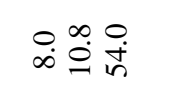 & $\stackrel{1}{r}$ \\
\hline & $m$ & $8 \pm$ & 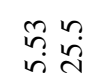 & $\stackrel{0}{r} \underset{i}{0}$ & $\grave{g}$ \\
\hline & $N$ & in in & 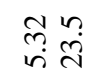 & $\because \stackrel{\infty}{\therefore} \stackrel{\infty}{\stackrel{\infty}{\infty}}$ & $\stackrel{+}{\circ}$ \\
\hline & - & in $\stackrel{\infty}{+}$ & $\stackrel{n}{m} \stackrel{2}{\square}$ & 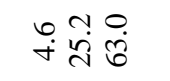 & तु่ \\
\hline 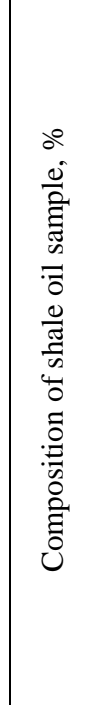 & & 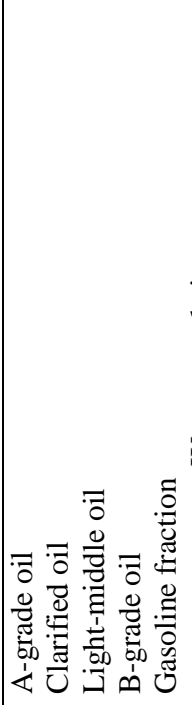 & 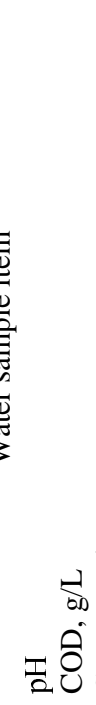 & 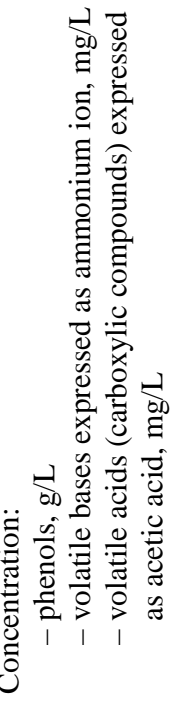 & 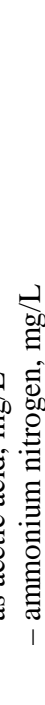 \\
\hline
\end{tabular}


Concentration of phenols in laboratory phenolic water samples, obtained by washing model samples of shale oil and gasoline fraction, varied from 1 to $8 \mathrm{~g} / \mathrm{L}$, that of volatile acids and bases in total is below $90 \mathrm{mg} / \mathrm{L}$ in the water from shale oil washing and below $160 \mathrm{mg} / \mathrm{L}$ in the water from gasoline fraction washing. It follows that the concentration of volatile acids and bases is one order of magnitude less than the minimal phenol concentration and has only a negligible influence on the linear dependence of COD on phenol concentration $\left(R^{2}=0.9904\right.$, see Figure).

The data in Table 2 demonstrate that washing of A- and/or B-grade oils and retort oils with A- or B-grade oil addition results in an increase in phenol concentration. At washing retort oil only, phenol concentration is $4.6 \mathrm{~g} / \mathrm{L}$, at washing sample 4 , this number is $8.0 \mathrm{~g} / \mathrm{L}$. The corresponding values for $\mathrm{pH}$ are 4.35 to 5.46. The last changes, in its turn, have a negative influence on the dephenolation process. At full substitution of light-middle oil with B-grade oil or heavy oil with A-grade oil, $\mathrm{pH}$ increases to 4.92.

Phenol water of retort oil washing contains twice as much volatile bases as the water of washing A- and/or B-grade oils. Changes in concentration of volatile acids (40-60 mg/L in average) in phenol water samples occur due to variations in gasoline fraction content of oil samples. Volatile acid content of phenolic waters exceeds that of volatile bases two-three times.

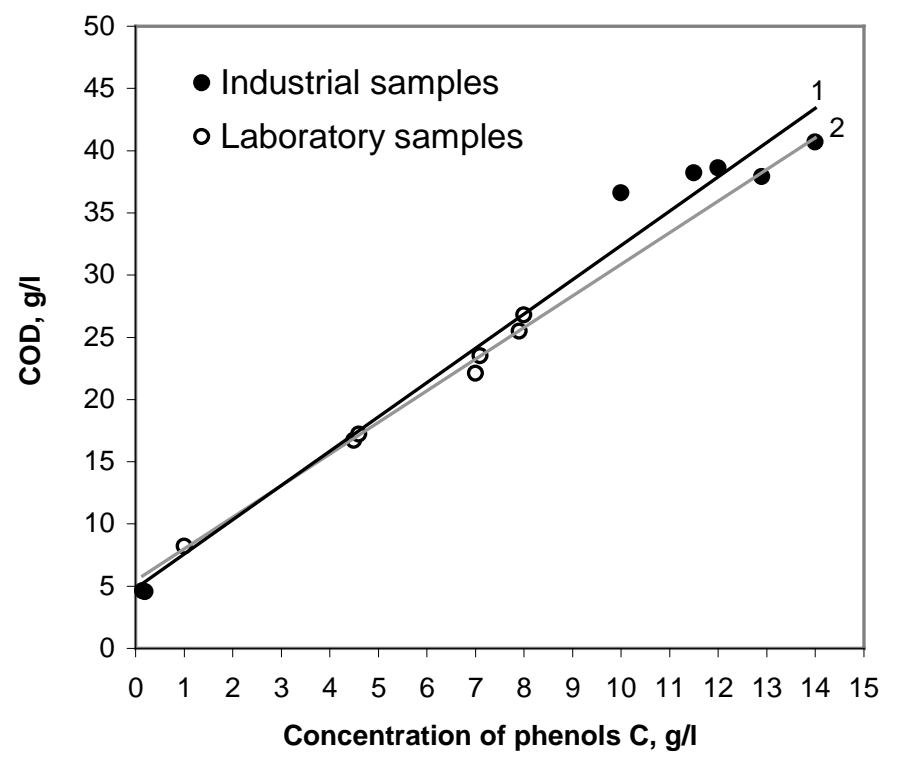

Figure. Dependence of COD of phenolic water on concentration of phenols.

1 - Industrial samples: $\mathrm{COD}(\mathrm{g} / \mathrm{l})=2.7567 \mathrm{C}+4.8133 ; \mathrm{R}^{2}=0.9783,2$ - Laboratory samples: $\mathrm{COD}(\mathrm{g} / \mathrm{l})=2.5411 \mathrm{C}+5.4429 ; \mathrm{R}^{2}=0.9904$. 


\section{Investigations of industrial phenol waters}

Characteristics of industrial phenolic water samples taken in the period of co-treatment of Kiviter and Galoter oils are presented in Table 3.

Phenol content of industrial phenolic waters varies in wide limits $(0.15$ $14 \mathrm{~g} / \mathrm{L}$, Table 3), and total content of acids and bases is about ten times higher than that of laboratory samples (that of bases is $482-580 \mathrm{mg} / \mathrm{L}$, of acids - 744-912 mg/L). The last numbers do not change much in course of the dephenolation process, but phenols' content decreases from $10-14 \mathrm{~g} / \mathrm{L}$ to $0.2 \mathrm{~g} / \mathrm{L}$. The dependence of COD of industrial water samples on phenol concentration is illustrated in Figure $\left(R^{2}=0.9783\right)$.

Table 3. Characteristics of industrial phenol water samples

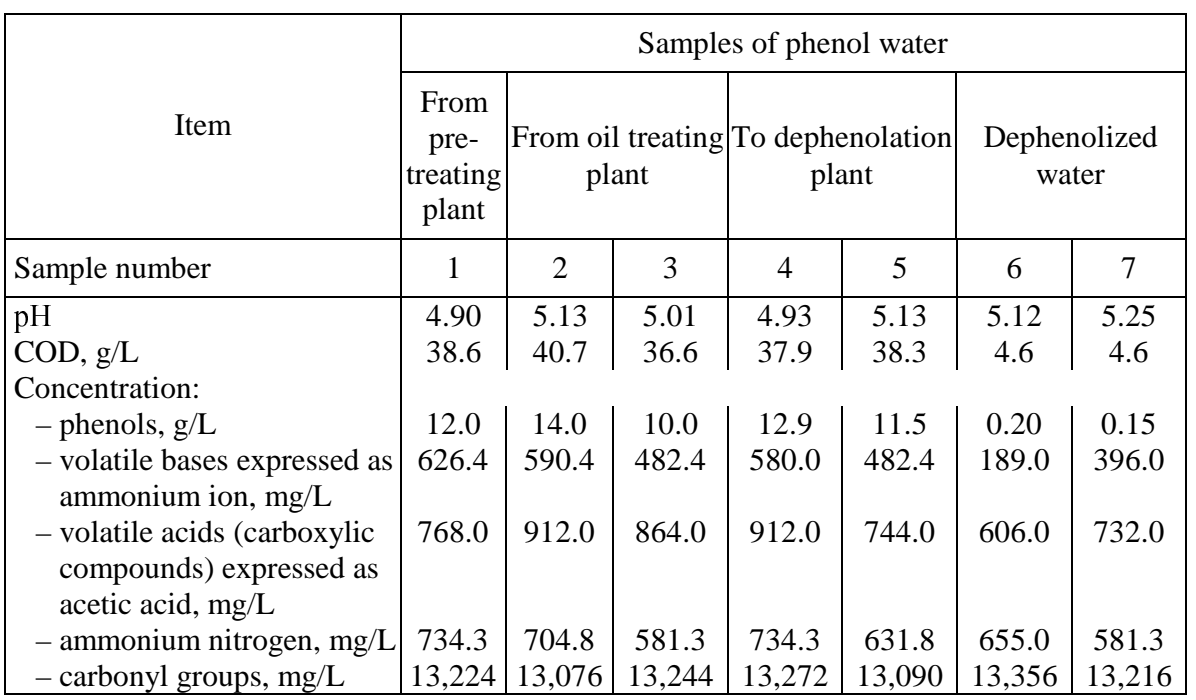

At the final stage of the dephenolation process, dephenolized water is steam-distilled to remove remnants of the extraction agent. Carbonyl compounds, which also influence COD of the water further directed to biological treatment, are also partly removed.

For determination of the influence of phenols and other compounds on COD of water, a model sample of dephenolized water was prepared.

\section{Modelling of dephenolized waters}

Standard solutions of 5-methyl resorcinol (separated from the concentrate of oil shale phenols, recrystallized, $99 \%$ pure) were prepared to study the influence of phenols on COD of phenolic water. Concentration of 5-MR solution was varied from $80 \mathrm{mg} / \mathrm{L}$ to $8,000 \mathrm{mg} / \mathrm{L}$ considering actual concentration of industrial waters entering and leaving the dephenolation plant. Concentration of total phenols was measured spectrophotometrically as all 
phenols, in spite of their structure, absorb the light in the region around $295 \mathrm{~nm}$ [12]. Characteristics of 5-MR solutions are given in Table 4.

The influence of carbonyl compounds on waters' COD was studied testing water solutions containing acetone $\left(\mathrm{Me}_{2} \mathrm{CO}\right.$, Penta, p.a.). The influence of compounds containing carboxyl groups and nitrogen was tested using disodium salt of ethylene diamine-N,N,N,N-tetraacetic acid $\left(\mathrm{Na}_{2}-\mathrm{EDTA}\right.$, Merck, p.a.).

As a model of water leaving the dephenolation plant a solution containing 5-MR, $\mathrm{Me}_{2} \mathrm{CO}$ and $\mathrm{Na}_{2}$-EDTA was prepared. The solution is characterized by $\mathrm{COD}-3,590 \mathrm{mg} / \mathrm{L}, \mathrm{pH}-4.90$, quantity of $0.5 \mathrm{M} \mathrm{NaOH}$ solution equivalent to $0.5 \mathrm{M}$ solution of $\mathrm{NH}_{2} \mathrm{OH} \cdot \mathrm{HCl}-2.8 \mathrm{~cm}^{3}$. So, these properties of the model solution are near to those of dephenolized water.

Contribution of each component to the COD value was calculated using calibration equations. Corresponding data are given in Table 5.

The calculated value of $\mathrm{COD}_{\text {calc }}(3,562 \mathrm{mg} / \mathrm{L})$ differs from the measured one $(3,590 \mathrm{mg} / \mathrm{L})$ by $0.8 \%$.

The calculated contribution of 5-MR to COD is less than $11 \%$ of actual COD of the prepared solution. It means that COD of dephenolized water is mainly influenced by other compounds.

Table 4. The influence of concentration $(C)$ of 5-MR, $\mathrm{Me}_{2} \mathrm{CO}$ and $\mathrm{Na}_{2}$-EDTA on COD of their solutions

\begin{tabular}{|c|c|c|c|c|c|}
\hline \multicolumn{2}{|c|}{$5-\mathrm{MR}$} & \multicolumn{2}{c|}{$\mathrm{Me}_{2} \mathrm{CO}$} & \multicolumn{2}{c|}{$\mathrm{Na}_{2}$-EDTA } \\
\hline $\begin{array}{c}C, \\
\mathrm{mg} / \mathrm{L}\end{array}$ & $\begin{array}{c}\mathrm{COD}, \\
\mathrm{mg} / \mathrm{L}\end{array}$ & $\begin{array}{c}C, \\
\mathrm{mg} / \mathrm{L}\end{array}$ & $\begin{array}{c}\mathrm{COD}, \\
\mathrm{mg} / \mathrm{L}\end{array}$ & $\begin{array}{c}C, \\
\mathrm{mg} / \mathrm{L}\end{array}$ & $\mathrm{COD}, \mathrm{mg} / \mathrm{L}$ \\
\hline 80 & 163 & 3,960 & 7,850 & 14 & 10 \\
160 & 327 & 7,920 & 15,700 & 71 & 49 \\
800 & 1,604 & 15,850 & 32,150 & 285 & 196 \\
4,000 & 8,020 & 39,610 & 87,130 & 712 & 490 \\
8,000 & 16,040 & 79,230 & 166,000 & 1,424 & 980 \\
\hline
\end{tabular}

Table 5. Contribution of individual components to COD of the model solution

\begin{tabular}{|c|c|c|c|}
\hline Component & $\begin{array}{l}\text { Concentration } C, \\
\mathrm{mg} / \mathrm{L}\end{array}$ & Calculation equation & $\begin{array}{c}\mathrm{COD}_{\text {calc }}, \\
\mathrm{mg} / \mathrm{L}\end{array}$ \\
\hline 5-MR & 185 & $\begin{array}{c}\mathrm{COD}\left(\mathrm{aq}^{*}, \mathrm{mg} / \mathrm{L}\right)=2.0045 c+2.9756 \\
\mathrm{R}^{2}=1\end{array}$ & 374 \\
\hline $\mathrm{Me}_{2} \mathrm{CO}$ & 1,190 & $\begin{array}{c}\mathrm{COD}(\mathrm{aq}, \mathrm{mg} / \mathrm{L})=2.1177 c-311.59 \\
\mathrm{R}^{2}=0,9999\end{array}$ & 2208 \\
\hline $\mathrm{Na}_{2}$-EDTA & 1,425 & $\begin{array}{c}\mathrm{COD}(\mathrm{aq}, \mathrm{mg} / \mathrm{L})=0.6881 c-0.1492 \\
\mathrm{R}^{2}=1\end{array}$ & 980 \\
\hline \multicolumn{3}{|r|}{ Total: } & 3562 \\
\hline
\end{tabular}

${ }^{*}$ aq - water 


\section{Conclusions and recommendations}

Research results have shown that the less phenols in water, the greater the influence of organic and other oxidizable compounds on water COD value. In case phenol concentration is $8 \mathrm{~g} / \mathrm{L}$, the share of other compounds is $40 \%$, but if it is as low as $0.2 \mathrm{~g} / \mathrm{L}$, the share of other compounds increases up to $90 \%$.

The calculations were based on calibration equation for 5-MR, the main component of water-soluble phenols in shale oil, and on equations expressing the dependence of COD value on phenol concentration in laboratory samples.

The results confirm general regularities describing the influence of oxidizable compounds on COD of both washing waters (after extraction) of model oil samples and industrial waters.

To reduce COD values of dephenolized waters leaving the dephenolation unit and entering the sewage treatment plant, it is absolutely necessary to reduce both concentration of phenols and that of oxidizable compounds at the stage of shale oil treatment. The final stage of the dephenolation process must guarantee maximum removal of extraction agent residue and carbonyl compounds.

\section{REFERENCES}

1. Soone, J., Doilov, S. Sustainable utilization of oil shale resources and comparison of contemporary technologies used for oil shale processing // Oil Shale. 2003. Vol. 20, No. 3S. P. 311-323.

2. Estonian Governmental Regulation no. 269 from the 21st of July 2001. Effluent guidelines for wastewater discharges to reservoirs and surface waters // RT 1 2001, 69, 424 [in Estonian].

3. Kolesnikov, V. P., Vilson, E. V. Modern development of operation processes of sewage purification at combined installations. - Rostov-on-Don: Yug Publishing House, 2006. 213 pp.

4. Kahru, A., Põllumaa, L. Environmental hazard of the waste streams of Estonian oil shale industry: an ecotoxicological review // Oil Shale. 2006. Vol. 23, No. 1. P. 53-93.

5. Mölder, L. Problems of formation and treatment of waters from oil shale processing. - Proceedings of International Seminar UNEP. Ecologically acceptable usage of low-grade fuels. Moscow, 1990, part 3, P. 28-53 [in Russian].

6. Kamenev, I., Munter, R., Pikkov, L., Kekisheva, L. Wastewater treatment in oil shale chemical industry // Oil Shale. 2003. Vol. 20, No. 4. P. 443-458.

7. Tiikma, L., Mölder, L., Tamvelius, H. Resources of water-soluble alkylresorcinols in oil fractions and retort water formed by processing oil shale in generators of high unit capacity // Oil Shale. 1991. Vol. 8, No. 4. P. 350-354.

8. Eisen, O., Hallik, E., Klesment, I. Die Zusammensetzung der wasserlöslichen neutralen Sauerstoffverbindungen des Brennschieferöls// Proc. Acad. Sci. 
Estonian SSR. 1966. Vol. XV, No. 2. P. 230-238 [in Russian, summary in German].

9. Metsik, R., Pevkur, T. A., Rohumagi, E. I. Research of group composition of sulphide compounds in products of shale thermal treatment // Extraction and processing of oil shale. 1969. Vol. 18. P. 170-176 [in Russian].

10. Kundel, H., Aitsen, E. Characteristics of phenol waters from PO "Slantsekhim" // Oil Shale Industry. 1986. No. 5. P. 15-17 [in Russian].

11. Oil Factrory production. Eesti Energia, AS Narva Elektrijaamad (Estonian Energy, Narva Power Plants). Factory standard EE 10579981-NJ ST9:2005. Eesti Energia, 2005. 24 pp.

12. Zhiryakov, Yu., Kundel, H., Romanchenko, L., Surnina, M. Determination of phenols content in oil shale process water// Oil Shale. 1989. Vol. 6, No. 2. P. 195-201 [in Russian, with English summary].

13. ISO 5664:1984 Water quality - Determination of ammonium - Distillation and titration method (http://www.iso.org).

14. ISO 6060:1989 Water quality - Determination of the chemical oxygen demand (http://www.iso.org).

Received January 13, 2006 